\title{
NEW DIRECTIONS IN AMERICANIST ARCHAEOLOGY
}

As we approach the end of this millennium, archaeologists are once again in the midst of serious and sometimes heated discussions about the nature of our discipline. But unlike the 1960s and the emergence of the new archaeology, what we are experiencing today has many more dimensions to it. Yes, we are debating issues pertaining to the different intellectual frameworks within which archaeological knowledge is developed. The number of techniques available to archaeologists to gain information about the past has grown enormously, as has our apparent difficulty assessing the reliability of archaeological method in relation to substantive claims. Yet this is not all. The institutional position of archaeology is also of concern. For instance, to what extent do our ideas about the past reflect the historical and contemporary conditions of Western society? How, then, has this context affected archaeological knowledge? Similarly, what should our relationship be to others (e.g., Native Americans, Native Hawaiians) who claim a historical connection to and moral concern about the archaeological record? What can we do about preserving historic properties for the future? Will the discipline continue to grow in terms of jobs available for our students? How does the growth of employment in research and contract-based archaeology relate to our concerns for the preservation of the archaeological record?

Possibly, the reasons for this most recent period of change may be of some interest to future historians of the discipline. For the moment, we can simply acknowledge that the transition we are experiencing is a result of our discipline's self-conscious emphasis on intellectual growth (Clarke 1973); a corresponding commitment to improve the technological capacity for observing and communicating aspects about the past (Bishop 1992); and the considerable alterations we have witnessed in the social and political contexts of the world today (e.g., Wylie 1992). In this sense the trend that began with the new archaeology continues, although clearly some of the more recent developments were not anticipated by the original protagonists.

All of this has made for some uneasiness among archaeologists. In contrast to the optimistic predictions of the new archaeology, it is unclear to many that this period of introspection and discussion foreshadows a more powerful interpretive paradigm or that it will necessarily lead to positive changes in the profession. This time the issues being raised are not solely about the development of archaeological knowledge, and there is now the realization that the success of ideas in the discipline is not always just a matter of their intellectual merit. Yet, Sabloff (1992) has recently suggested that much of this may not really matter to most archaeologists because these issues concern only a small portion of the profession. I would rephrase this; these issues may not appear to matter to many archaeologists because their relevance to the practice of our discipline remains poorly sketched. I would argue, however, that the multidimensional nature of archaeology today makes it increasingly likely that the various discussions about the discipline will affect most of us who work in the profession. Further, in at least one respect I am encouraged by the debate that now regularly occurs in the pages of American Antiquity, for I regard this as an opportunity to identify the relations among ideas and of these to the practice and organization of Americanist archaeology.

As Redman (1991:297) has observed, many Americanist archaeologists have now implemented one of the most important tenets of the new archaeology: that our research must involve an explicit consideration of method and theory. In so doing we have moved past the sociological (but not necessarily, the construct [cf. Meltzer 1979:647]) paradigm of culture history. However, as most of us are also painfully aware, self-conscious good intentions will not necessarily produce useful

American Antiquity, 59(1), 1994, pp. 5-8.

Copyright (C) 1994 by the Society for American Archaeology 
archaeological method and theory. As a result, archaeologists still grapple with the issue of which theoretical perspective our discipline should develop and maintain and how to connect this through method (or middle-range theory) to understand the past (see, for example, contributions in LambergKarlovsky [1989]; Meltzer et al. [1986]; Pinsky and Wylie [1989]; Preucel [1991]; Wandsnider [1992]).

It occurs to me that much of what this current discussion is about pertains to the kind of discipline archaeology is or can become: a natural science, a social science, or a humanity (or some category not represented by these labels). For archaeology each of these kinds of disciplines constitutes a different perspective and set of construct paradigms on how to interpret the world (Dunnell 1982). What constitutes the "stuff" of explanation or understanding also varies considerably across these kinds of disciplines. The standards employed to evaluate conclusions are somewhat different among the perspectives as well. Yet the differences that separate such disciplines (or competing interpretive models within a particular kind of discipline) have received only partial treatment, and then, typically by an advocate of one particular perspective in which the others are described in less-than-flattering terms. We need to identify points of convergence as well as divergence for the competing perspectives in archaeology. There should be some assessment of their success in achieving stipulated goals.

Archaeologists have added to the confusion about the nature of our profession, when for political purposes we represent archaeology to the public and to ourselves as integrating all three of these kinds of disciplines. This would not be problematic except that at the same time many archaeologists promote the concept of a unified and cohesive intellectual framework. Clearly, some honest selfexamination is in order. We cannot have both a diversity of interpretive approaches and theoretical unification across the discipline.

A number of the solutions have been sought to resolve this dilemma. Over the past decade there has been a retreat from theory among some archaeologists into the domain of method or technical expertise, i.e., computation or instrumentation. One outcome of this has been an increase in the specialized analyses of archaeological materials accompanied by limited kinds of inferences. Others have built networks of communication and reciprocal citation within their particular interpretive perspective, writing for those who share a common conceptual framework. Neither of these seems a particularly suitable resolution to the problem, although their etiology is certainly understandable. Without some attempt to understand each other we face the prospect of professional fragmentation, replicating what has happened and is happening within anthropology.

Let me suggest a more pragmatic solution to this dilemma that does not necessarily privilege one kind of discipline over the other and may help at the same time to maintain some of the cohesion that Americanist archaeology has enjoyed. At one level it should be possible to recognize our common ground-the archaeological record. We have established a tradition in archaeology for the relatively careful observation of the preserved remnants of the past. And although these observations are not neutral with respect to theory, at the same time there is general agreement on the fundamental importance of such observations as well as many of the characteristics that we are expected to observe, record, and describe. So, too, do archaeologists concur that materials should be precisely recovered from the archaeological record. The last decade has also found considerable agreement among archaeologists (who may otherwise disagree on virtually everything else) on the importance of researching and identifying the effects of natural (and at least some of the cultural) formation processes on the archaeological record (Schiffer 1987). Finally, we all seek ways of preserving significant components of the archaeological record, not only for our future archaeological investigation, but because they provide tangible evidence for the historical heritage of various peoples around the world. Although these represent contexts of ongoing research, we can continue to expect a high degree of concordance among archaeologists for implementing the results of their investigation.

On a theoretical level, archaeologists are joined by an ontological position that assigns a behavioral or ethnological reality to the past (Meltzer 1979:653). This reality, however constituted interpretively, must be linked to the material remains and the relations of the archaeological record. In between these areas of overlap among approaches are methods and interpretive models which are in need of additional review and systematic assessment. As Watson (1991:269) has noted there is substantially more overlap within what have seemed to be distinctive approaches (e.g., the new 
archaeology and postprocessual archaeology) than has been heretofore acknowledged. Similarly, there is substantial agreement on the proper application and evaluation of certain methods (e.g., seriation) in archaeology, irrespective of the interpretive paradigm one has chosen.

Nonetheless, there are differences that need to be addressed, especially insofar as those differences lead to fundamentally different conclusions about the past. Thus far, many of the differences identified have provided only labels and have yet to treat the underlying construct relations that give rise to the differences. Only by giving sustained attention to these matters can archaeologists begin to consciously choose what it is they want to do and say and what they consider to be the most appropriate disciplinary and interpretive means to achieve their research objectives.

It may still be possible to maintain our theoretical diversity in archaeology without doing damage to the organization of our profession. However, to do so requires far greater attention to the kind of discipline we represent in our research and the proper role of method and theory within that discipline and in relation to our conclusions.

I think it is fair to say that during the past 20 years American Antiquity has represented the social science aspect of archaeology, as this has been and continues to be the dominant institutional setting for and focus of Americanist archaeology. In this respect the new archaeology has been an unqualified success. However, this may be about to change, as the theoretical implications of different interpretative approaches are realized.

As the editor of this journal I am undoctrinaire when it comes to appreciating good archaeological research. While my theoretical interests now emphasize evolutionary topics, I encourage contributions to the application of critical theory, the interpretation of political economy, various postprocessual interpretive views, or the development of historically based understandings of the past (and the present). My concern is that archaeologists identify the intellectual perspective within which research is done and then hold that research to its own standards (and those widely shared in the discipline), especially as regards logical consistency, theoretical coherence, and empirical sufficiency. Moreover, in my view some of the best papers published in American Antiquity are those which have combined some discussion of method and theory with substantive results or unanticipated implications (e.g., Binford 1965; Braun and Plog 1982; Schiffer 1972; Wobst 1974). This has been true, even for papers whose theory or conclusions I may have disputed. Among my most important duties as editor, then, is to encourage authors to establish a linkage between the substantive and theoretical or methodological portions of their research. Additionally, I regard the demonstration of analytical sufficiency to be an important desideratum in Americanist archaeology. In this sense I am not a relativist; good scholarship should transcend its perspective, and I hope to publish such research in the pages of American Antiquity.

Michael W. Graves

Editor

\section{REFERENCES CITED}

Binford, L. R.

1965 Archaeological Systematics and the Study of Culture Process. American Antiquity 31:203-210.

Bishop, R. L.

1992 Instumentation and the Future of Archaeology. In Quandaries and Quests: Visions of Archaeology's Future, edited by L. Wandsnider, pp. 160-169. Occasional Paper No. 20. Center for Archaeological Investigations, Southern Illinois University, Carbondale.

Braun, D. P., and S. L. Plog

1982 Evolution of "Tribal" Social Networks: Theory and Prehistoric North American Evidence. American Antiquity 47:504-525.

Clarke, D. L.

1973 Archaeology: The Loss of Innocence. Antiquity 47:417-422.

Dunnell, R. C.

1982 Science, Social Science, and Common Sense: The Agonizing Dilemma of Modern Archaeology. Journal of Anthropological Research 38:1-25.

Lamberg-Karlovsky, C. C. (editor)

1989 Archaeological Thought in America. Cambridge University Press, Cambridge. 
Meltzer, D. J.

1979 Paradigms and the Nature of Change in American Archaeology. American Antiquity 44:644-657.

Meltzer, D. J., D. D. Fowler, and J. A. Sabloff (editors)

1986 American Archaeology Past and Future: A Celebration of the Society for American Archaeology 19351985. Smithsonian Institution Press, Washington, D.C.

Pinsky, V., and A. Wylie (editors)

1989 Critical Traditions in Contemporary Archaeology: Essays in the Philosophy, History and Socio-politics of Archaeology. Cambridge University Press, Cambridge.

Preucel, R. W.

1991 Processual and Postprocessual Archaeologies: Multiple Ways of Knowing the Past. Occasional Paper No. 10. Center for Archaeological Investigations, Southern Illinois University, Carbondale.

Redman, C. L.

1991 Distinguished Lecture in Archeology: In Defense of the Seventies-The Adolescence of New Archeology. American Anthropologist 93:295-307.

Sabloff, J. R.

1992 Visions of Archaeology's Future: Some Comments. In Quandaries and Quests: Visions of Archaeology's Future, edited by L. Wandsnider, pp. 266-272. Occasional Paper No. 20. Center for Archaeological Investigations. Southern Illinois University, Carbondale.

Schiffer, M. B.

1972 Archaeological Context and Systemic Context. American Antiquity 37:156-165.

1987 Formation Processes of the Archaeological Record. University of New Mexico Press, Albuquerque.

Wandsnider, L. (editor)

1992 Quandaries and Quests: Visions of Archaeology's Future. Occasional Paper No. 20. Center for Archaeological Investigations, Southern Illinois University, Carbondale.

Watson, P. J.

1991 A Parochial Primer: The New Dissonance as Seen from the Midcontinental United States. In Processual and Postprocessual Archaeologies: Multiple Ways of Knowing the Past, edited by R. W. Preucel, pp. 265-274. Occasional Paper No. 10. Center for Archaeological Investigations, Southern Illinois University, Carbondale.

Wobst, H. M.

1974 Boundary Conditions for Paleolithic Social Systems: A Simulation Approach. American Antiquity 39: 147-178.

Wylie, A.

1992 The Interplay of Evidential Constraints and Political Interests: Recent Archaeological Research on Gender. American Antiquity 57:15-35. 